\title{
Compliance to Corporate Governance among Publicly-listed Companies in the Philippines
}

\section{Joel B Tan}

Faculty, College of Accounting Education, University of Mindanao, Davao City, 8000 Philippines

*Corresponding author: Dr. Joel B Tan, Faculty, College of Accounting Education, University of Mindanao, Davao City, 8000 Philippines, Tel: +63 (082) 932-853-9934; E-mail: tan_joel@umindanao.edu.ph

Received date: January 03, 2015, Accepted date: January 13, 2015, Published date: January 20, 2015

Copyright: (c) 2015 Tan JB. This is an open-access article distributed under the terms of the Creative Commons Attribution License, which permits unrestricted use, distribution, and reproduction in any medium, provided the original author and source are credited.

\begin{abstract}
In the present corporate world, code of governance plays a major role in assessing a company's strengths and weaknesses. A company which implements a sound corporate code of governance tends to maximize the quality of its assets and enterprise value with respect to its shareholders. Such company also gives the impression of transparency and fairness in dealing to all stakeholders. The study randomly selected and downloaded thirty publicly-listed companies with annual reports in 2012 in the Philippine Stock Exchange (PSE) to answer the research instruments specially developed for the study. The paper used descriptive-quantitative design. Frequency and percentage method and ANOVA were used to determine the significant difference between the independent and dependent variables. The results revealed that companies' characteristics have no significant difference and did not influence the level of compliance to corporate governance among the respondents. Nevertheless, most businesses that are publicly-listed have high compliance to the requirements of the Securities of Exchange and Commission (SEC) particularly to the compliance, communication and reportorial processes in order to operate efficiently, to attract potential investors and to disclose information about security risks and associated events to protect the interest of the shareholders.
\end{abstract}

Keywords: Accounting; Corporate governance; Compliance; Publicly-listed companies; Quantitative research; Descriptive design; Davao city; Philippines

\section{Introduction}

An organization which has effective corporate controls will most likely prevent any conflict of interest between those insiders who directly manage company affairs and those passive investors. Without constant disagreements and doubts inside the organization, it will lead to enhance the firm's value and improve its management efficiency. By implementing good governance, a firm can provide relevant information to external users through quality financial reports [1].

Based on the study of Koehn and Ueng [2], one cannot distinguish whether a good financial information provided came from a company that practices strong corporate governance or not. Even firms with poor corporate governance can also produce good reports.

However, Faber [3] discovered that a company which had experiences in committing fraud in one way or another find it difficult to overcome the stigma for a long time, even after correcting its ways by practicing good governance. Hence, it is still doubtful whether those which practice good governance in a corporate environment can achieve the ultimate goal of producing more accurate and transparent financial reporting.

There have been a number of valuable studies in corporate governance and these studies are more on the impact of corporate governance on the financial performance [4] and compliance with modern legislations to corporate governance and its implementation in the companies [5]. However, none of these provided the compliance to corporate governance among publicly-listed companies in the Philippines.

\section{Framework}

This study was anchored in the study of Sarbanez-Oxley Act [6] which was a by-product of the corporate governance challenges in America. It posited that it is the management's responsibility to establish structures and procedures for financial reporting at the same time maintain adequate internal control.

The Philippine Securities and Exchange Commission (SEC) [7] issued Memorandum Circular 2, also known as the Code of Corporate Governance. The Code aims to encourage reforms in corporate governance in order to develop the capital market, lift-up investors' confidence in the market and as a result sustain the growth of the economy as well as the corporate sector.

Further, Kothari expounded that the quality of accounting information is not only influenced by the quality of accounting standards but also constituted by the nature of corporate governance. The legal system and the existence and enforcement of effective laws that govern the accounting standards are IFRS and conceptual framework. This consequently highlights the important role played by corporate governance in shaping the quality of financial reporting in organizational settings and in ensuring credibility and integrity of the governance. Many users of financial information are interested in the performance and potential of one particular part of the company's operations or the other, rather than the company as a whole. 
Citation: Tan JB (2015) Compliance to Corporate Governance among Publicly-listed Companies in the Philippines. Bus Eco J 6: 133. doi:

Page 2 of 4

\section{Method}

\section{Research design and respondents}

This study used quantitative descriptive method. The respondents of the research were publicly-listed companies in the Philippines with 2012 annual reports in the Philippine Stock Exchange. They were purposively selected in the PSE website.

\section{Research instrument}

The instrument used in this study was a validated self-constructed survey questionnaire. It is designed to draw information on the compliance of the companies to the code of corporate governance. The questionnaire is divided into two (2) parts: Part 1 is to determine the company's characteristics and Part 2 is to determine the level of compliance to Corporate Governance in terms of compliance, communication and reportorial processes.

\section{Data gathering procedure}

The sampling plan included 30 annual reports of publicly-listed companies that have been taken in the PSE web site.

\section{Results and Discussion}

As observed in Table 1, 66.67\% of the respondents belong to service industry. Service industry tops most in the publicly-listed companies, $46.67 \%$ of the respondents have been operating more than 50 years, and $56.67 \%$ of the respondents have more than 10 billion assets.

\begin{tabular}{|c|c|c|}
\hline Descriptive Characteristics & Frequency & Percentage (\%) \\
\hline \multicolumn{3}{|l|}{ Nature of Business } \\
\hline Manufacturing & 8 & 26.67 \\
\hline Merchandising & 2 & 6.67 \\
\hline Services & 20 & 66.67 \\
\hline \multicolumn{3}{|l|}{ Company Age } \\
\hline Less than 10 years & 3 & 10.00 \\
\hline $10-30$ Years & 8 & 26.67 \\
\hline $30-50$ Years & 5 & 16.67 \\
\hline More than 50 Years & 14 & 46.67 \\
\hline \multicolumn{3}{|l|}{ Total Assets } \\
\hline Less than 350 million & 3 & 10.00 \\
\hline 350 million to 1 billion & 3 & 10.00 \\
\hline 1 billion to 5 billion & 4 & 13.33 \\
\hline 5 billion to 10 billion & 3 & 10.00 \\
\hline More than 10 billion & 17 & 56.67 \\
\hline
\end{tabular}

Table 1: Company Characteristics.

Table 2 revealed that the publicly-listed companies highly complied with the code in terms of compliance process, communication process and reportorial process with the corresponding percentage of $89 \%$, $86 \%$ and $85 \%$, respectively.

\begin{tabular}{|l|l|l|l|}
\hline Level of Compliance & Frequency & Percentage & Descriptive Meaning \\
\hline Indicators & 400 & $89 \%$ & Signifies a high compliance to the code \\
\hline Compliance Process & 154 & $86 \%$ & Signifies a high compliance to the code \\
\hline Communication Process & 153 & $85 \%$ & Signifies a high compliance to the code \\
\hline Reportorial Process & & & \\
\hline
\end{tabular}

Table 2: Level of Compliance. 
Citation: Tan JB (2015) Compliance to Corporate Governance among Publicly-listed Companies in the Philippines. Bus Eco J 6: 133. doi:

Page 3 of 4

\begin{tabular}{|l|l|l|l|l|l|l|}
\hline $\begin{array}{l}\text { Level of Compliance to } \\
\text { Corporate Governance }\end{array}$ & \multicolumn{2}{|l|}{ Nature of Business } & F-value & P-value & Decision on Ho \\
\hline & Manufacturing & Merchandising & Services & & & \\
\hline Compliance Process & 0.8833 & 0.9667 & 0.8833 & 0.38 & 0.688 & Accept \\
\hline Communication Process & 0.8125 & 0.8333 & 0.8750 & 0.50 & 0.611 & Accept \\
\hline Reportorial Process & 0.8958 & 0.8333 & 0.8333 & 0.27 & 0.768 & Accept \\
\hline Overall & 0.8639 & 0.8778 & 0.8639 & 0.02 & 0.985 & Accept \\
\hline
\end{tabular}

Table 3.1: Significant Difference on Company's Compliance to the Code of Corporate Governance by Nature of Business.

\begin{tabular}{|l|l|l|l|l|l|l|l|}
\hline $\begin{array}{l}\text { Level of Compliance } \\
\text { Corporate Governance }\end{array}$ & \multicolumn{4}{|l|}{ Company Age } & F-value & P-value & Decision on Ho \\
\hline & $\begin{array}{l}\text { Less than } \mathbf{1} \\
\text { Year }\end{array}$ & $\mathbf{1 - 3}$ Years & $\mathbf{3 - 5}$ Years & $\begin{array}{l}\text { More than } \\
\text { Years }\end{array}$ & & & \\
\hline Compliance Process & 0.9111 & 0.9083 & 0.8933 & 0.8714 & 0.17 & 0.919 & Accept \\
\hline Communication Process & 1.000 & 0.8333 & 0.8667 & 0.8333 & 1.11 & 0.363 & Accept \\
\hline Reportorial Process & 0.8889 & 0.8750 & 0.9000 & 0.8095 & 0.34 & 0.795 & Accept \\
\hline Overall & 0.9333 & 0.8722 & 0.8867 & 0.8381 & 0.81 & 0.502 & Accept \\
\hline
\end{tabular}

Table 3.2: Significant Difference on Company’s Compliance to the Code of Corporate Governance by Company Age.

\begin{tabular}{|c|c|c|c|c|c|c|c|c|}
\hline \multirow{2}{*}{$\begin{array}{l}\text { Level of Compliance to } \\
\text { Corporate Governance }\end{array}$} & \multicolumn{5}{|l|}{ Company Age } & \multirow[t]{2}{*}{ F-value } & \multirow[t]{2}{*}{ P-value } & \multirow[t]{2}{*}{ Decision on Ho } \\
\hline & $\begin{array}{l}\text { Less than } \\
50 \mathrm{M}\end{array}$ & $50 \mathrm{M}$ to $150 \mathrm{M}$ & $\begin{array}{l}150 \mathrm{M} \\
250 \mathrm{M}\end{array}$ & $\begin{array}{l}250 M \\
350 M\end{array}$ to & $\begin{array}{l}\text { More than } \\
350 \mathrm{M}\end{array}$ & & & \\
\hline Compliance Process & 0.8889 & 0.8889 & 0.7500 & 0.9556 & 0.9098 & 1.63 & 0.199 & Accept \\
\hline Communication Process & 0.9444 & 0.8333 & 0.8333 & 0.8889 & 0.8431 & 0.33 & 0.852 & Accept \\
\hline Reportorial Process & 1.000 & 0.6667 & 0.7083 & 0.9444 & 0.8725 & 1.97 & 0.130 & Accept \\
\hline Overall & 0.9444 & 0.7963 & 0.7639 & 0.9296 & 0.8752 & 2.42 & 0.075 & Accept \\
\hline
\end{tabular}

Table 3.3: Significant Difference on Company's Compliance to the Code of Corporate Governance by Total Assets.

Tables 3.1 to 3.3 revealed that the level of compliance to the code and the companies' characteristics are not related to each other. It means further that one will not depend on the other and the companies' characteristics will not affect the level of compliance to the code of corporate governance. For this reason, there was an acceptance of the null hypothesis which states that there is no significant difference of the level of compliance to corporate governance when respondents are grouped according to profile.

\section{Conclusion}

According to statistical results, in terms of compliance, communication and reportorial processes, the level of the companies' compliance to corporate codes have been highly complied. In determining the significant difference in the level of compliance to corporate governance when respondents are grouped by profiles, the proposed hypothesis has been accepted that there is no significant difference between the main and moderating variables. This means that their profile does not affect or does not have an impact on their compliance to the code.

\section{References}

1. Chalaki P, Didar H, Riahinezhad M (2012) Corporate governance attributes and financial reporting quality: Empirical evidence from Iran. International Journal of Business and Social Science 3: 25-36.

2. Koehn D, Ueng J (2010) Corporate governance metrics for asian companies: Are they reliable indicators of corporate performance? International Journal of Business Governance and Ethics 5: 241.

3. Farber DB (2005) Restoring trust after fraud: Does corporate governance matter?. Rochester: Social Science Research Network.

4. Soti, Pravesh, Gupta, Sachindra Kr (2013) "Impact of corporate Governance on the Financial Performance of Indian it companies Listed on stock Exchange" International Journal of Management, Research, Reviews. 
Citation: Tan JB (2015) Compliance to Corporate Governance among Publicly-listed Companies in the Philippines. Bus Eco J 6: 133. doi: 10.4172/2151-6219.1000133

Page 4 of 4

5. Todorovic, Zdravko, Todorovic, Igor (2012) "Compliance with modern legislations of corporate governance and its implication in the companies "Montenegrin Journal of Economics.

6. Oxley Act (2002) Retrieved on December 16, 2013 from http:// www.auditshark.com/Education/what-is-sox-compliance.aspx
7. SEC (2002) Retrieved on January 28, 2014 from:https://www.sec.gov/ rules/proposed/proposedarchive/proposed2002.shtml. 